\title{
When strike fails: The role of personal significance and positive expectations in maintaining a commitment to worker protests.
}

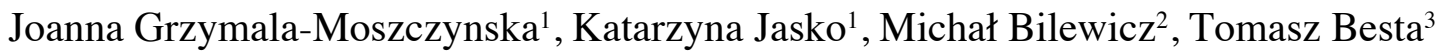 \\ 1 - Jagiellonian University, Poland; 2 - University of Warsaw, Poland, 3 - University of Gdansk, Poland
}

Author Correspondence: j.grzymala.moszczynska@gmail.com

Funding: This research was supported by a grant from the National Science Center (2015/19/B/HS6/ 01253) 


\begin{abstract}
In the current paper, we address psychological mechanisms predicting commitment to collective action for labor rights. Specifically, we focus on factors that helped maintain engagement in a workers' cause among participants of a failed teachers' strike. We examined the relative role of positive and negative experiences and how they related to a sense of personal significance as motivators of further collective action after the failure of a national strike that a large group of teachers participated in. We also compared the effects of experienced emotional states with the effects of expectancy of success. The results suggest that when people experienced a boost in feelings of significance, even if the collective action failed, they were more willing to participate in a future collective action. We also found that expectancy was related to willingness to take part in another strike or other protest actions, which is in line with past studies.
\end{abstract}

Keywords: protests, collective action, strike, significance quest, positive emotions 


\section{Introduction}

Failure is the mother of success.

Chinese proverb

The situation of workers has been negatively impacted by increasing economic inequalities, weakening labor laws, and the rising precarity of employment worldwide. Due to the COVID-19 pandemic, many employees have already experienced a direct threat to their health and lives, as well as layoffs, pay cuts, and high uncertainties about their economic future (ILO, 2020). In addition, union membership and collective bargaining agreements have declined in recent times (OECD, 2017; 2019). Thus, even though an increasing number of people suffer from difficulties in the workplace, only a minority of them decide to challenge these conditions.

One reason for this might be that workers' protests often encounter harsh responses from governments and corporations, and engagement in such actions may come at a high personal cost. Moreover, actions aimed at improving working conditions rarely bring immediate success, and it often takes a long time before their effects can be seen. For example, limiting the workday to eight hours and securing paid holidays took over a century of effort before succeeding (Foner, 1986). Given these circumstances, what are the psychological factors that predict commitment to collective action for labor rights? What helps maintain engagement in a workers' cause after a setback, when discouragement and withdrawal are more likely? The present study's goal is to address these questions in the context of an unsuccessful teachers' strike.

\section{Predictors of Collective Action}

Past research on collective action has focused on grievances and relative deprivation as primary motivators (Gurr, 1970; Merton, 1957; Pettigrew, 1967). It showed that when people perceive their situation as unjust and feel that they are deprived of what they deserve, the 
probability of getting involved in actions aimed at changing their situation increases. The robustness of this phenomenon was supported by the meta-analysis of more than 200 studies (Smith, Pettigrew, Pippin, \& Bialosiewicz, 2012), which additionally showed that anger experienced in reaction to injustice facilitates participation (e.g., Miller, Cronin, Garcia, \& Branscombe, 2009; Tausch \& Becker, 2013; Van Zomeren, 2013). The relationship between the perception of injustice, negative emotions evoked by such a perception, and engagement in collective actions was also investigated in labor relations research (Klandermans, 1986; Schutt, 1982; Wheeler, 1983). For instance, studies have shown that perceived maltreatment in the workplace, low job satisfaction, and financial inadequacy are positively related to union membership (Green \& Heywood, 2015; Johnson \& Jarley 2004; Nagi \& Pugh, 1973), participation in strikes, and even aggression against management (Hill, 2009; Sen, 2011).

However, resentment or a sense of injustice might not be enough if people do not expect that their actions will actually succeed. According to the expectancy-value theory of collective action (Klandermans, 1982), people will participate in a social movement when the cause is personally important. However, they also need to believe that their participation will ensure success. This notion is supported by studies on collective efficacy, which showed that when people perceive their group to be efficacious, they are more willing to join a protest (Fox \& Schofield, 1989; van Zomeren, Spears, Fischer \& Leach, 2004). In contrast, individuals who lack hope that other people will rise with them to face a shared problem are less likely to support and engage in collective actions (Marlon et al., 2019; Wlodarczyk et al., 2017). In the context of the labor movement, studies have shown that workers who considered union strategy as effective were more willing to participate in union actions (Klandermans, 1984). 
In short, the literature on collective action and the labor movement suggests that people are more likely to participate in collective action when they are frustrated and when they also believe their actions can mitigate the situation. However, this perspective has several limitations. First, the overall strength of the relation between angry resentment and engagement is not very strong, which suggests that there is more at play than just negative emotions and frustration. Second, evidence suggests that people engage in collective actions even when the expectancy of success is very low (Klandermans \& Oegema, 1987; Sturmer \& Simon, 2004). Additionally, people often maintain their commitment to a cause despite experiencing repeated failures (Tausch \& Becker, 2013).

Drawing on the quest for significance theory (Kruglanski, Jasko, Chernikova, Webber, \& Dugas, 2017), we suggest that additional motivational factors might explain commitment in the face of a defeat. Specifically, we propose that positive feelings gained from engagement in a cause, particularly a sense of pride, meaning, and personal significance, are vital for long-term engagement in a collective cause.

\section{Personal Significance from Collective Action}

According to the quest for significance theory (Kruglanski et al., 2017), people have a fundamental need to feel valued and important and to live a meaningful life. On the one hand, the frustration of these needs (i.e., a loss of significance) caused by unfair treatment, humiliation, or disrespect evokes a person's motivation to restore their feelings of significance. It can motivate political protest (Jasko et al., 2020), endorsement of extreme ideology (Webber et al., 2018), or attraction to a radical group (Schumpe et al., 2019). On the other hand, engagement in a meaningful struggle for an important cause provides people with a sense of personal significance 
and pride. These experiences may be rewarding on their own-even when the cause's goals have not materialized - and can motivate further commitment.

Past studies confirm that participation in collective actions is often associated with positive states, such as empowerment (Besta, Jaśkiewicz, Kosakowska-Berezecka, Lawendowski, \& Zawadzka, 2018; Drury \& Reicher, 2005), pride (Tausch \& Becker, 2013), and a sense of belonging (Renström, Bäck \& Knapton, 2018). Previous studies also support the notion that personal significance gained through political activism predicts commitment to future actions (Jasko, Szastok, Grzymala-Moszczynska, Maj, \& Kruglanski, 2019). The research showed that, among committed activists, personal significance was a stronger predictor of commitment to a cause than the negative affect experience (e.g., outrage, disrespect) that first prompted the action. One study conducted specifically in the context of labor protests showed that feelings of pride and personal significance experienced by protesting medical professionals predicted their willingness to self-sacrifice and engage in collective actions in the future (Jasko et al., 2019).

Although these studies support the idea that a sense of personal significance can help maintain a commitment to a cause, none was conducted in a situation where the collective action failed. Thus, it is unclear whether the effects of a positive psychological state would also be obtained in such a situation. Second, only a small part of the psychological research on collective action has been done in the context of labor relations. Thus, investigating the predictors of collective action in this context is not only important from a practical standpoint but is theoretically important as well.

To summarize, we propose that when people experience a sense of personal significance from participation in collective action for labor rights, they will remain committed to the cause even when they have experienced recent failure and long-term success is uncertain. These 
feelings could be an even stronger motivator than the original frustrations that prompted the cause (i.e., a sense of humiliation or lack of respect).

\section{Current Research}

We tested our predictions in a large sample of teachers who took part in a strike in April 2019. The Polish Teachers' Union (the largest teachers' labor union in Poland) organized the strike. Importantly, even though Poland's unionization level is low, its largest share of union members $(23.2 \%)$ work in education (GUS, 2019). The strike was preceded by a referendum, in which approximately $78 \%$ of the participating schools supported the decision to go on strike. According to the union data, 15,179 schools - close to $75 \%$ of all public schools in Polandjoined the strike. Nearly 600,000 people, including teachers and school administrators, participated in it, making it the largest strike in the Polish education system since 1993.

The strike received support from $44 \%$ of all Poles and $50 \%$ of Poles with school-age children (CBOS, 2019). However, on April 27, 2019, the strike was suspended after three weeks. The majority of strike demands had not been realized at that moment. When the strike was suspended, the union authorities announced the plans for resumption of the strike in the fall. Despite the announcement, neither the strike nor other forms of teachers' protests resumed.

The data in this study were collected two months after the strike and during a period when teachers' organizations and trade unions were considering the possibility of another strike in September 2019. The goal was to examine what would predict teachers' willingness to engage in another strike or other forms of future protest. Our main predictors were teachers' experiences

during the past protest. Specifically, we measured the extent to which teachers experienced a gain of personal significance (i.e., pride, empowerment) during their engagement in the strike, as well as a loss of personal significance (i.e., disrespect, humiliation) they felt in this situation. We also 
examined the role of expectancy of success. Finally, we conducted additional analyses that explored the correlates of emotional experiences during the strike. Specifically, we were interested in the role of social support that teachers received inside and outside the protest groups.

\section{Method}

The data were collected online from June 15 to July 8, 2019, among teachers working in Polish public schools. The study was conducted in cooperation with a teachers' grassroots organization (i.e., a Nationwide Interschool Strike Committee), which helped distribute the survey invitations.

Participants. Participants were recruited through internal online forums, mailing lists, and teachers' discussion groups on social media. The invitations to participate in the study were sent to teachers with diverse experiences working in various locations. Our sample consisted of 7,238 teachers, of which 6,474 participated in the spring strike (3642 women, 444 men, 6 other; $\left.M_{\text {age }}=43.78, S D=9.18\right)$, constituting approximately $1.4 \%$ of the general population of teachers in Poland (GUS, 2018). Teachers participating in the study were representative of the teachers' population in terms of gender and stage of their professional career, as presented in Table 1 in SOM. As the study was conducted online and a relatively large number of people started but did not finish the survey, we indicate a specific sample size for each analysis. The participants who participated in the spring strike, answered at least $50 \%$ of items on the scales, and had completed measures of our focal variables are included in the analyses $(N=4,161)$. Materials, data and code are available on OSF at https://osf.io/yw8s2/?view_only=4936096b39f04ef1a9f838afd12a7e2b

Measures. If not mentioned otherwise, all questions were answered on a scale ranging from 1 (Definitely not) to 5 (Definitely yes). 
Past engagement in the strike. All participants were asked about their involvement in the nationwide strike in the spring of $2019(1=$ "Yes, I was involved," $0=$ "No, I was not involved in the strike"). All the analyses are conducted only on data from individuals who participated in the strike, which constituted $83 \%$ of our sample.

Perception of the spring strike. To gain insight into whether the strike was considered a defeat, we asked two questions. One item directly measured the perceived success of the past strike: "Do you think the goals of the spring strike were achieved?" Another question measured the assessment of the decision to suspend the strike, where participants answered on a scale from 1 ("It was definitely a mistake") to 5 ("It was definitely a good decision").

Perceived need of strike resumption. We measured the perceived need for resumption of the strike by one question: "Do you think that a strike announcement in the fall is needed?".

Expectancy of future success. Next, we measured the expected success of the future strike: "How do you view the chances of the success of a future strike in the fall?" Participants responded on a scale from 1 (Definitely low) to 5 (Definitely high).

Gain of personal significance. We measured the personal significance respondents gained from participating in the past strike by asking them to recall the extent to which they felt proud, strong, and significant during the strike $(\alpha=.77)$.

Loss of personal significance. The loss of personal significance experienced by participants in the teachers' strike was measured by asking them about the extent to which they felt humiliated and disrespected during the strike $(r=.47, p<.001)^{1}$.

1 We also measured how weak and powerless they felt; however, in the presented analysis we only include the first two items. Additional analysis performed with an index of all four items did not change the pattern of the results. 
Intention to participate in the strike. Participants indicated their willingness to engage in another strike in the fall of 2019.

Intention to participate in moderate and radical collective actions. We also measured the willingness to engage in forms of protest other than a strike. Five questions measured willingness to participate and organize moderate collective actions such as demonstrations, debates, and teachers' meetings $(\alpha=.81)$. Another three items measured willingness to engage in radical actions such as blocking streets, going on a hunger strike, and occupying a school $(\alpha=.76)$. We excluded one item (i.e., "Withdrawing from optional, nonobligatory tasks (e.g., school trips)") because it only weakly correlated with the other items in the scales.

\section{Additional variables.}

Solidarity and support among teachers. Three questions measured perceived solidarity and integration among teachers $(\alpha=.74)$. The first question was, "During the strike, the teaching community in Poland was: 1 (Definitely divided) - 5 (Definitely integrated)." We also asked the same question referring to "the teachers working in my facility." The third question was, "During the strike, did you feel any support from your colleagues?"

Social support. Four questions assessed perceptions of community support for the strike. “During the strike, did you feel any support from: their family, students' parents; students, public opinion" $(\alpha=.64)$. 


\section{Results}

First, we describe the teachers' psychological situation during the strike and after it was suspended to examine whether the situation was indeed perceived by protesting teachers as a defeat. Next, we present our main analyses regarding willingness to engage in future strike and other protest activities. Finally, we present exploratory analyses to examine the correlates of teachers' emotional experience during the protest.

Perceptions of the strike. On average, teachers agreed that the past strike's goals had not been achieved $(M=1.76, S D=0.95)$. They also expressed mixed opinions about the strike suspension $(M=2.78, S D=1.69)$ but generally believed another strike in the fall was needed $(M$ $=3.38, S D=1.28$ ). Teachers recalled both high levels of significance gain (positive feelings) and significance loss (negative feelings) during the strike. This suggests high emotional involvement in the protest.

Interestingly, despite the perceived need to announce another strike, there was little expectation of its success $(M=2.20, S D=1.08)$. Nevertheless, $43 \%$ of teachers declared that they would be willing to strike again, as indicated by their responses above the scale's midpoint. In contrast, over $30 \%$ of respondents did not want to participate in the strike at the time of survey completion $(M=3.22, S D=1.52)$.

The exact means, confidence intervals, and correlations for our focal variables (i.e., feelings of significance gain and loss, the expectancy of success, and collective action intentions) are presented in Table 1. The scatterplots illustrating those relationships are presented in Fig. 1. 
Table 1. Descriptive Statistics and Correlations

\begin{tabular}{|c|c|c|c|c|c|c|}
\hline & $\begin{array}{c}\text { Significance } \\
\text { loss }\end{array}$ & $\begin{array}{c}\text { Expectancy of } \\
\text { success }\end{array}$ & $\begin{array}{c}\text { Willingness } \\
\text { to strike } \\
\text { again }\end{array}$ & Moderate actions & $\begin{array}{l}\text { Radical } \\
\text { actions }\end{array}$ & $\begin{array}{c}M \\
{[95 \% C I]}\end{array}$ \\
\hline $\begin{array}{l}\text { Significance } \\
\text { gain }\end{array}$ & $-.20^{* * * *}$ & $.28^{* * *}$ & $.36^{* * *}$ & $.31^{* * * *}$ & $.23^{* * *}$ & $3.80[3.77,3.83]$ \\
\hline $\begin{array}{l}\text { Significance } \\
\text { loss }\end{array}$ & & $-.14^{* * *}$ & $-.09^{* * *}$ & $-.07^{\text {**** }}$ & $-.04^{* *}$ & $3.96[3.92,3.99]$ \\
\hline $\begin{array}{l}\text { Expectancy } \\
\text { of success }\end{array}$ & & & $.66^{* * *}$ & $.34^{* * *}$ & $.32^{* * *}$ & $2.20[2.17,2.23]$ \\
\hline $\begin{array}{l}\text { Willingness } \\
\text { to strike }\end{array}$ & & & & $.44^{* * *}$ & $.40^{* * *}$ & $3.22[3.18,3.26]$ \\
\hline again & & & & & & \\
\hline $\begin{array}{l}\text { Moderate } \\
\text { actions }\end{array}$ & & & & & $.42^{* * *}$ & $3.29[3.26,3.32]$ \\
\hline $\begin{array}{l}\text { Radical } \\
\text { actions }\end{array}$ & & & & & & $2.38[2.34,2.41]$ \\
\hline
\end{tabular}



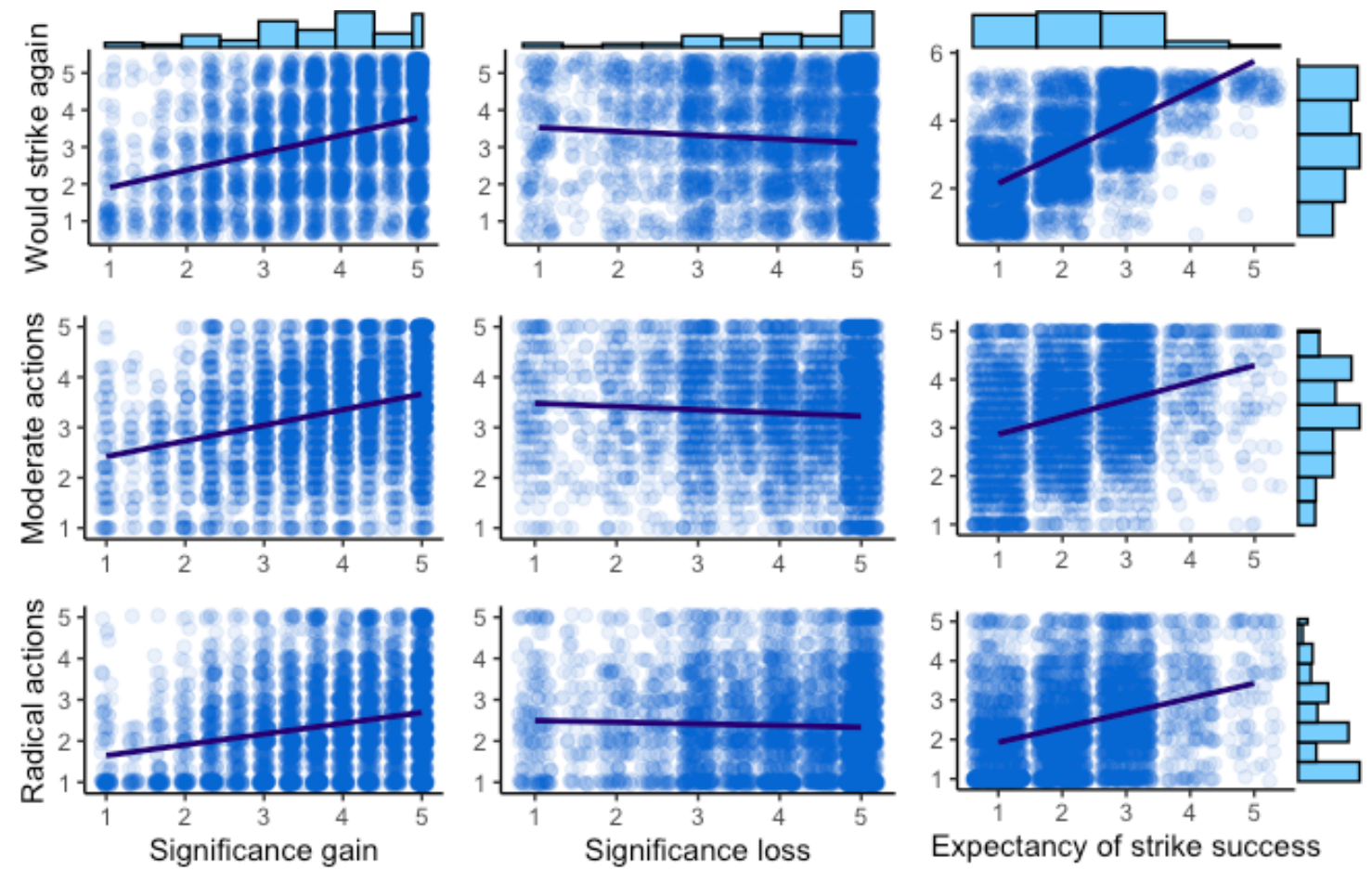

Fig. 1 Relations between collective action intentions and feelings of significance gain, significance loss, and expectancy of success.

Commitment to future protest. To test our main hypotheses, we conducted three regression analyses, one for every outcome variable (i.e., intentions to engage in the future strike, intentions to participate in moderate and radical collective actions). In the first step of each analysis, we entered the significance gain and significance loss teachers experienced during the protest. In the second step, we added the expectancy of success of the future strike. The results are presented in Table 2 .

The effect of significance gain on willingness to strike again was positive $(b=0.47,95 \%$ $\mathrm{CI}[0.43,0.50], \beta=.36, p<.001)$. In contrast, significance loss was not significantly related to willingness to strike again $(b=-0.02,95 \% \mathrm{CI}[-0.05,0.02], \beta=-.01, p=.34)$. Expectancy of success of the future strike, entered in the second step, was a strong and positive predictor $(b=$ 
$0.83,95 \%$ CI $[0.80,0.87], \beta=.61, p<.001)$. However, even after including it in the model, significance gain was still positively related to strike intention.

Similar effects could be observed concerning intentions to participate in moderate and radical forms of protest. Significance gain was a positive predictor of those intentions (moderate actions: $b=0.31,95 \%$ CI $[0.28,0.34], \beta=.30, p<.001$, radical actions: $b=0.26,95 \%$ CI $[0.23$, $0.30], \beta=.24, p<.001)$. In contrast, significance loss was not significantly related to intentions to participate in future protest actions. Significance gain remained a positive predictor even when expectancy was included in the model, which in itself was a positive predictor of collective action intention. 
Table 2. Regression results

\begin{tabular}{|c|c|c|c|c|c|c|}
\hline & $\boldsymbol{B}$ & $S E$ & Beta & $\boldsymbol{B}$ & $S E$ & Beta \\
\hline \multicolumn{7}{|c|}{ Willingness to strike again } \\
\hline Significance gain & 0.47 & 0.02 & $.36 * * *$ & 0.26 & 0.02 & $.20 * * *$ \\
\hline Significance loss & -0.02 & 0.02 & -.01 & 0.04 & 0.01 & $.04 * *$ \\
\hline Expectancy of success & & & & 0.83 & 0.02 & $.61 * * *$ \\
\hline \multicolumn{7}{|l|}{ Moderate actions } \\
\hline Significance gain & 0.31 & 0.02 & $.31 * * *$ & 0.24 & 0.02 & $.23 * * *$ \\
\hline Significance loss & -0.01 & 0.01 & -.01 & 0.01 & 0.01 & .02 \\
\hline Expectancy of success & & & & 0.29 & 0.02 & $.28 * * *$ \\
\hline \multicolumn{7}{|l|}{ Radical actions } \\
\hline Significance gain & 0.26 & 0.02 & $.24 * * *$ & 0.18 & 0.02 & $.16 * * *$ \\
\hline Significance loss & 0.01 & 0.02 & .01 & 0.03 & 0.02 & $.03 *$ \\
\hline Expectancy of success & & & & 0.33 & 0.02 & $.28 * * *$ \\
\hline
\end{tabular}

Additional analyses. To gain insights into correlates of emotional experience during the strike, we also present the results of additional exploratory analyses focused on the role of social support coming from the ingroup (i.e., other teachers) and different outgroups varying in closeness (i.e., family, neighbors, students and their parents, and the general public; see Table 3). Generally, teachers perceived their ingroup solidarity as relatively high during the strike $(M=$ 3.92, $S D=0.99$ ). At the same time, they experienced less support from students and their parents, 
the local community, and public opinion. The feelings of support and solidarity from the school community and observers, as well as the experience of integration among teachers, were all positively related to feelings of significance gain during the strike. In other words, teachers who experienced solidarity with other teachers and received support from close and distant others felt more significant during the protest. The opposite (but weaker) trend was found concerning significance loss, namely, people who felt unsupported experienced more significance loss.

Table 3. Social support and significance experienced during the strike.

\begin{tabular}{lllc}
\hline & $\begin{array}{c}\text { Significanc } \\
\text { e gain }\end{array}$ & $\begin{array}{c}\text { Significance } \\
\text { loss }\end{array}$ & $\begin{array}{c}M \\
{[95 \% \mathrm{CI}]}\end{array}$ \\
\hline Solidarity among teachers & $.28 * * *$ & $-.04 *$ & $3.92[3.89,3.94]$ \\
Support from family & $.24 * * *$ & -.02 & $4.29[4.26,4.32]$ \\
Support from parents & $.13 * * *$ & $-.07 * * *$ & $2.81[2.76,2.85]$ \\
Support from students & $.16 * * *$ & $-.04 *$ & $2.84[2.80,2.89]$ \\
Support from public opinion & $.19 * * *$ & $-.15 * * *$ & $2.10[2.07,2.13]$ \\
$* p<.05 ; * * p<.01, * * * p<.001$ & & &
\end{tabular}

\section{Discussion}

While past collective action research offers important insights into the conditions that facilitate a person's decision to join a social movement, the studies devote much less attention to maintaining commitment following initial recruitment. Moreover, collective frustration and the expectancy of success remain considered as the key predictors of collective action (Bandura, 2000; van Zomeren, Spears, Fischer, \& Leach, 2004; van Zomeren, Postmes, \& Spears, 2008). This is despite the research indicating political participation could be a source of many positive psychological experiences on its own, even when the outcomes of those actions are often uncertain, delayed in time, or simply negative (Drury \& Reicher, 2005, Tausch \& Becker, 2013). To address these gaps, taking a large group of teachers participating in a national strike as our 
sample, we examined the relative role of positive and negative experiences related to a sense of personal significance as motivators of further collective action after a failure. We also compared these effects with those concerning the expectancy of success.

In line with past studies, we found that expectancy was indeed related to willingness to take part in a strike again, as well as in other protest actions. More importantly, we also found that even in a failed collective action, when people experienced a boost in feelings of significance, they were more willing to participate in collective action. Specifically, when they associated positive experiences with their past participation in a strike, they declared a higher willingness to participate in both moderate and radical actions in the future. Importantly, the expectancy of success did not eliminate those effects. Even after a defeat, the loss of personal significance did not significantly predict collective action intentions.

These findings point to the importance of psychological factors that enable persistence in collective action despite experiencing failure. Research devoted to activist burnout suggests that prolonged exposure to high stress and negative emotions can lead to dropping out from a movement (Nagoski \& Nagoski, 2019). Therefore, it is crucial to understand the motivating role of positive experiences associated with political participation. The fact that motivations are built not only on expectations of success, but can also be created based on meaning and pride, are important insights for those working toward social change in areas where the chances of success are highly uncertain.

Moreover, the contrast between the present findings and other studies on collective action that demonstrate the important role of negative emotions such as anger and outrage (Becker \& Tausch, 2015) suggests that different factors may play a role at different stages of collective action. This would be in line with Brown and Pickerill's (2009) observations of British anti- 
capitalist movements. They suggested that although an initial decision to join a movement may be related to negative emotions, different emotional strategies are necessary to avoid activist burnout in a movement's later stages. Similarly, integrative models based on social identity theory suggest that the experience of achievement emotions (e.g., pride) could motivate activists to participate in future collective action (Becker \& Tausch, 2015). At the same time, these findings are also in line with research on long-term commitment in other domains, which is strongly predicted by positive and rewarding experiences associated with goal pursuit (Woolley \& Fishbach, 2017).

Although this study was conducted on a large and relatively representative sample of a population of teachers participating in a strike, it has several limitations. Based on such a research design, we cannot be confident about the role of strike failure in the observed results. Further study of successful collective actions that would assess the influence of experiencing significance gain and significance loss would be needed to test whether the observed patterns of results are specific to collective action failure or could also be applied to predicting willingness to maintain engagement after successful collective actions. As the study is correlational, it is plausible that the declarations of pride or strength could be psychological justifications of intention to engage in further action (in a dissonance-reducing way, Harmon-Jones, Harmon-Jones, \& Levy, 2015). As much as we find the presented pattern more plausible, we hope that future experimental and longitudinal studies could also test alternative causal inferences.

The present study also addresses the significant gap in psychological research on collective actions, as a review of the literature devoted to those issues suggests that labor activism is rarely studied in the field (only 7/69 and 11/68 citations include labor activism in Smith et al. 2012 and Van Zomeren, Postmes \& Spears 2008 review papers, respectively). It is especially 
important to study those mechanisms in the context of an increasing number of labor protests that could be observed worldwide, such as teachers' protests in the US in 2018-19, the Yellow Vests movement in France, or the 2019 mass protests in Chile. Although there has already been evidence that personal significance gained through political activism is positively related to commitment to future actions (Jasko et al., 2019), this study presents novel insights into the roles that positive emotions and psychological significance play in maintaining engagement in collective action. We accomplish this by showing the role of personal significance in a relatively understudied context of the labor movement and, more importantly, by showing that people's feelings of significance could remotivate further actions even in the case of failure. In sum, even though self-interest and simple cost-benefit estimations were considered the primary source of motivation for engagement in labor unions for a long time (Chawla, Singh, Ringh \& Agarwal, 2018), our study suggests that emotional factors and social support may also play an important role in this process.

The experience of the teachers' labor movement in Poland reflects many similar historical situations in which objectively unsuccessful collective actions form a psychological basis for more successful actions in the future by generating a sense of significance among the participants. The May 1968 student protests in France, UK miners' strike in the 1980s, or Poland's Solidarity in 1980-81 are examples of collective actions that experienced setbacks but created a strong sense of personal significance among participants and ultimately inspired longterm changes in their respective countries. Those mechanisms and the role of experiencing feelings of solidarity among strike participants could be interesting issues for future exploration. The role of solidarity as a factor potentially mitigating the harmful effects of lack of social 
support, which is a frequent experience in many collective actions, could be particularly interesting.

\section{References}

Bäck, E. A., Bäck, H., \& Knapton, H. M. (2015). Group belongingness and collective action: Effects of need to belong and rejection sensitivity on willingness to participate in protest activities. Scandinavian Journal of Psychology, 56(5), 537-544.

Becker, J. C., \& Tausch, N. (2015). A dynamic model of engagement in normative and nonnormative collective action: Psychological antecedents, consequences, and barriers. European Review of Social Psychology, 26, 43-92.

Besta, T., Jaśkiewicz, M., Kosakowska-Berezecka, N., Lawendowski, R., \& Zawadzka, A. M. (2018). What do I gain from joining crowds? Does self-expansion help to explain the 
relationship between identity fusion, group efficacy and collective action. European Journal of Social Psychology, 48, 152-167.

Brown, G. \& Pickerill, J. (2009). Space for emotion in the spaces of activism. Emotion, Space and Society, 2, 24-35.

Bureau of Labor Statistics (2019). Retrieved from:

https://www.bls.gov/news.release/wkstp.nr0.htm

CBOS (2019). Społeczne poparcie dla protestu nauczycieli. Komunikat z badań, 54/2019.

Retrieved from: https://cbos.pl/SPISKOM.POL/2019/K_054_19.PDF

Chawla, G., Singh, T., Singh, R., \& Agarwal, S. (2018). Worker participation in union activities: a conceptual review. Personnel Review, 47(1), 206-226.

Drury, J. \& Reicher, S. (2005). Explaining enduring empowerment: A comparative study of collective action and psychological outcomes. European Journal of Social Psychology, $35,35-58$.

Foner, P. S. (1986). May Day: A Short History of the International Workers' Holiday, 18861986. International Publishers Co.

Fosh, P. (1993). Membership participation in workplace unionism: the possibility of union renewal. British Journal of Industrial Relations, 31(4), 577-592.

Fox, L. D., \& Schofield, J. W. (1989). Issue salience, perceived efficacy and perceived risk: A study of the origins of anti-nuclear war activity. Journal of Applied Social Psychology, 19(10), 805-827.

Gani, A. (1992). Membership participation in union activities. Indian Journal of Industrial Relations, 27(3), 243-258. 
Gurr, T. R. (1970). Sources of rebellion in Western societies: Some quantitative evidence. The Annals of the American Academy of Political and Social Science, 391(1), 128-144.

Harmon-Jones, E., Harmon-Jones, C., \& Levy, N. (2015). An action-based model of cognitivedissonance processes. Current Directions in Psychological Science, 24(3), 184-189.

Healy, G., \& Kirton, G. (2013). The Early Mobilization of Women Union Leaders - A Comparative Perspective. British Journal of Industrial Relations, 51(4), 709-732.

Hill, E. (2009). The Indian industrial relations system: struggling to address the dynamics of a globalizing economy. Journal of Industrial Relations, 51(3), 395-410.

Hornsey, M. J., Blackwood, L., Louis, W., Fielding, K., Mavor, K., Morton, T., . . White, K. M. (2006). Why do people engage in collective action? Revisiting the role of perceived effectiveness. Journal of Applied Social Psychology, 36(7), 1701-1722.

ILO (2020). ILO Monitor: COVID-19 and the world of work. Retrieved from: https://www.ilo.org/wcmsp5/groups/public/@dgreports/@dcomm/documents/briefingnote /wcms_749399.pdf

Jasko, K., Szastok, M., Grzymała-Moszczyńska, J., Maj, M. \& Kruglanski, A. W. (2019). Rebel with a Cause: Personal Significance from Political Activism Predicts Willingness to SelfSacrifice. Journal of Social Issues, 75, 314-349.

Johnson, N.B. and Jarley, P. (2004). Justice and union participation: an extension and test of mobilization theory, British Journal of Industrial Relations, 42(3), 543-562.

Klandermans, B. \& Oegema, D. (1987). Potentials, networks, motivations, and barriers: Steps towards participation in social movements. American Sociological Review, 52(4), 519531. 
Klandermans, B. (1984). Mobilization and participation in trade union action: an expectancyvalue approach. Journal of Occupational Psychology, 57(2), 107-120.

Klandermans, B. (1986). Psychology and trade union participation: joining, acting, quitting. Journal of Occupational Psychology, 59(3), 189-204.

Klein, O., Spears, R., \& Reicher, S. (2007). Social identity performance: Extending the strategic side of SIDE. Personality and Social Psychology Review, 11(1), 28-45.

Kruglanski, A. W., Jasko, K., Chernikova, M., Dugas, M. \& Webber, D. (2017). To the fringe and back: Violent extremism and the psychology of deviance. American Psychologist, 72, $217-230$

Marlon, J., Bloodhart, B., Ballew, M., Rolfe-Redding, J., Roser-Renouf, C., Leiserowitz, A., \& Maibach, E. (2019). How Hope and Doubt Affect Climate Change Mobilization. Frontiers in Communication, 4, 20.

Merton, R. K. (1957). Social structure and anomie. New York.

Miller, D. A., Cronin, T., Garcia, A. L., \& Branscombe, N. R. (2009). The relative impact of anger and efficacy on collective action is affected by feelings of fear. Group Processes \& Intergroup Relations, 12(4), 445-462.

Nagi, M. H., \& Pugh, M. D. (1973). Status inconsistency and professional militancy in the teaching profession. Education and Urban Society, 5(4), 385-403.

Pettigrew, T. F. (1967). Social evaluation theory: Convergences and applications. In Nebraska symposium on motivation. University of Nebraska Press.

Redman, T., \& Snape, E. (2004). Kindling activism? Union commitment and participation in the UK fire service. Human Relations, 57(7), 845-869. 
Renström, E. A., Bäck, H., \& Knapton, H. M. (2018). Conforming to Collective Action: The Impact of Rejection, Personality and Norms on Participation in Protest Activity. Social Psychological Bulletin, 13(4), 1-17.

Schumpe, B. M., Bélanger, J. J., Moyano, M. \& Nisa, C. F. (2018). The role of sensation seeking in political violence: An extension of the significance quest theory. Journal of Personality and Social Psychology, 118(4), 743-761

Schutt, R. K. (1982). Models of militancy: Support for strikes and work actions among public employees. ILR Review, 35(3), 406-422.

Sen, R. (2011). Multinationals \& Industrial relations in India. The Indian Journal of Industrial Relations, 46(3) 367-383.

Smith, H. J., Pettigrew, T. F., Pippin, G. M. i Bialosiewicz, S. (2012). Relative deprivation: A theoretical and meta-analytic review. Personality and Social Psychology Review, 16, $203-$ 232.

Stürmer, S. \& Simon, B. (2004). The role of collective identification in social movement participation: A panel study in the context of the German gay movement. Personality and Social Psychology Bulletin, 30, 263-277.

Tausch, N. \& Becker, J. C. (2013). Emotional reactions to success and failure of collective action as predictors of future action intentions: A longitudinal investigation in the context of student protests in Germany. British Journal of Social Psychology, 52, 525-542.

Van Zomeren, M. (2013). Four core social-psychological motivations to undertake collective action. Social and Personality Psychology Compass, 7(6), 378-388. 
van Zomeren, M., Postmes, T.\& Spears, R. (2008). Toward an integrative social identity model of collective action: a quantitative research synthesis of three socio-psychological perspectives. Psychological Bulletin, 134, 504-535.

Van Zomeren, M., Spears, R., Fischer, A. H. \& Leach, C. W. (2004). Put your money where your mouth is! Explaining collective action tendencies through group-based anger and group efficacy. Journal of Personality and Social Psychology, 87, 649-664.

Webber, D., Chernikova, M., Kruglanski, A. W., Gelfand, M. J., Hettiarachchi, M., Gunaratna, R., ... \& Belanger, J. J. (2018). Deradicalizing detained terrorists. Political Psychology, 39, 539-556.

Wheeler, K. G. (1983). Perceptions of labor market variables by college students in business, education, and psychology. Journal of Vocational Behavior, 22(1), 1-11.

Supplementary Materials

Table 1. Comparison of levels of teachers' professional career in the population and sample (based on governmental data)

\begin{tabular}{|c|c|c|c|c|c|}
\hline & $\begin{array}{c}\text { Trainee } \\
\text { teachers }\end{array}$ & Contract teachers & $\begin{array}{c}\text { Appointed } \\
\text { teachers }\end{array}$ & $\begin{array}{c}\text { Chartered } \\
\text { teachers }\end{array}$ & Women \\
\hline $\begin{array}{c}\% \text { in the } \\
\text { sample }\end{array}$ & $3 \%$ & $15 \%$ & $21 \%$ & $61 \%$ & $89 \%$ \\
\hline $\begin{array}{c}\% \text { in the } \\
\text { population }\end{array}$ & $4 \%$ & $16 \%$ & $22 \%$ & $55 \%$ & $82 \%$ \\
\hline
\end{tabular}

Percentages in the rows do not sum to $100 \%$, as there are $3 \%$ of teachers in the population without those titles. The table is based on the report: https://stat.gov.pl/obszary-tematyczne/edukacja/edukacja/oswiata-i-wychowanie-wroku-szkolnym-20172018,1,13.html 
